e-Journal Al-Syakhsiyyah: Journal of Law \& Family Studies, Vol. 2 No.1 (2020)

(C) Fakultas Syariah IAIN Ponorogo (2020)

Published Online ; Juni 2020

\title{
ADVANCE PRICING AGREEMENT DALAM PERSPEKTIF HUKUM PERJANJIAN
}

\author{
SESARIO AULIA
}

Fakultas Syariah Institut Agama Islam Negeri Ponorogo

sesario@iainponorogo.ac.id

\begin{abstract}
ABSTRAK : Menurut Pasal 1 Ayat (5) Peraturan Menteri Keuangan Republik Indonesia Nomor 22/PMK.03/2020 tentang Kesepakatan Harga Transfer (Advance Pricing Agreement) yang selanjutnya disebut APA adalah Perjanjian Tertulis antara Direktorat Jenderal Pajak dan Wajib Pajak atau Direktorat Jenderal Pajak dengan otoritas pajak pemerintah Mitra P3B yang melibatkan wajib pajak untuk menyepakati kriteria - kriteria dalam penentuan harga transfer dan/atau menentukan harga wajar atau laba wajar dimuka. Latar Belakang adanya APA adalah untuk mencegah praktek transfer pricing yang sudah menjadi masalah global, Transfer Pricing adalah bentuk usaha yang dilakukan oleh perusahaan multinasional demi megurangi beban pajak penghasilan dengan cara mentransfer laba perusahaan ke anak perusahaan yang mempunyai beban pajak yang lebih rendah, Transfer Pricing menjadi masalah serius dibidang perpajakan dikarenakan berpotensi menghilangkan pendapatan negara dari sektor pajak. Selain itu APA merupakan salah satu bentuk dari hukum perjanjian, lebih tepatnya kontrak publik, hal ini disebabkan oleh karena salah satu pihak yang terikat didalam kontrak adalah pemerintah. Penulisan artikel ini bertujuan untuk menggambarkan Perjanjian APA dari sudut pandang hukum perjanjian, metode pendekatan yang digunakan adalah pendekatan perundang undangan dan pendekatan konseptual. Pendekatan perundang - undangan wajib diperlukan untuk mengkaji kedudukan APA dari sudut pandang Kitab Undang Undang Hukum Perdata. Sementara itu Pendekatan konseptual, digunakan untuk mengkaji dan menganalisis kerangka pikir atau kerangka konseptual maupun landasan teoritis dari Perjanjian APA. Hasil penelitian menyimpulkan bahwa Perjanjian APA jelas merupakan bagian dari hukum perjanjian karena secara keseluruhan Perjanjian APA terikat dengan dasar-dasar hukum perjanjian.
\end{abstract}

Kata Kunci : Advance Pricing Agreement - Kontrak - Pajak

ABSTRACT : According to Article 1 Clause (5) Regulation of the Minister of Finance of the Republic of Indonesia No. 22/PMK. 03/2020 about Advance Pricing Agreement a.k.a an APA is an agreement between the Directorate General of Taxation and taxpayers or the Directorate General of Taxation with the government tax authority of the P3B partner involving taxpayers to agree on the criteria for determining transfer pricing and/or determining fair or reasonable profit upfront. The background of APA is to prevent the practice of transfer pricing that is already a global problem. Transfer Pricing means a form of business done by multinational companies in order to overburden income tax expense by transferring the profit of the 


\section{ADVANCE PRICING AGREEMENT \\ DALAM PERSPEKTIF HUKUM PERJANJIAN}

company to a subsidiary that has a lower tax burden, Transfer Pricing becomes a serious problem in the field of taxation due to potentially eliminating state revenue from the tax sector.

The writing of this article aims to describe the APA from the viewpoint of contract law, the method of approach used is the statutory approach and the conceptual approach. A statutory approach is required to examine the position of the APA from the perspective of the Civil law. Meanwhile, the conceptual approach is used to study and analyze the framework or conceptual framework and theoretical basis of the APA. The results of the study concluded that the APA is clearly part of the treaty law because overall the APA is bound by the legal basis of the contract.

Keywords : Advance Pricing Agreement - Contract - Tax

\section{PENDAHULUAN}

Istilah Transfer Pricing ialah suatu bentuk kegiatan yang dilakukan oleh perusahaan untuk memindahkan laba yang diperolehnya dari persuhaan yang memiliki beban pajak tinggi ke anak perusahaan lain yang memiliki beban pajak rendah, ada dua kategori transfer pricing yaitu : "intra company transfer pricing dan inter company transfer pricing. Intra company transfer pricing merupakan transfer pricing antardivisi dalam satu perusahaan. Sedangkan inter company transfer pricing merupakan transfer pricing antara dua perusahaan yang mempunyai hubungan istimewa. Transaksinya sendiri bisa dilakukan dalam satu negara (domestic transfer pricing), maupun dengan negara yang berbeda (international transfer pricing)" ${ }^{1}$ Transfer pricing ditinjau dari sudut pandang pemerintah disimpulkan sebagai salah satu faktor yang mengakibatkan berkurangnya bahkan dapat menghilangkan pendapatan negara dari sektor pajak, hal ini disebabkan oleh karena perusahaan multinasional memindahkan beban pajak yang diterimanya dari negara yang menerapkan beban nominal pajak yang tinggi ke negara yang menerapkan beban nominal pajak yang rendah.

Di Indonesia isu transfer pricing sendiri mulai dikenal sejak pemerintah mengeluarkan Surat Edaran Direktur Jenderal Pajak (DJP) Nomor: SE 04/PJ.7/1993 tanggal 3 September 1993 tentang Petunjuk Penanganan Kasus Transfer Pricing dan Surat Keputusan Direktur Jenderal Pajak No.01/PJ.7/1993 tanggal 9 Maret 1993 tentang Pedoman Pemeriksaan Pajak Terhadap Wajib Pajak Yang Mempunyai Hubungan Istimewa. Lalu klausula transfer pricing ini dimasukkan kedalam Perubahan Undang - Undang Pajak Tahun 2000. Pasal 18 Ayat (3a) Undang - Undang Pajak Penghasilan menyebutkan bahwa: "Direktur Jendral Pajak berwenang melakukan perjanjian dengan wajib pajak dan bekerja sama dengan pihak otoritas pajak negara lain untuk menentukan harga transaksi antar pihak-pihak yang mempunyai hubungan istimewa, yang berlaku selama suatu periode tertentu dan mengawasi

1 Hadi Setiawan,"Kajian Transfer Pricing Dan Risikonya Terhadap Penerimaan Negara.pdf, http://www.kemenkeu.go.id/sites/default/files/2014, akses 27 April 2020 


\section{ADVANCE PRICING AGREEMENT \\ DALAM PERSPEKTIF HUKUM PERJANJIAN}

pelaksanaannya serta melakukan renegosiasi setelah periode tertentu tersebut berakhir". ${ }^{2}$ Penjelasan pasal tersebut menyatakan bahwa: "kesepakatan harga transfer Advance Pricing Agreement (APA) adalah kesepakatan antara Wajib Pajak (WP) dengan Drektorat Jenderal Pajak (DJP) mengenai harga jual wajar produk yang dihasilkannya kepada pihak - pihak yang mempunyai hubungan istimewa (related parties) dengannya." 3 APA bertujuan untuk mencegah terjadinya kegiatan transfer pricing perusahaan multinasional yang dapat merugikan negara. APA dapat memberikan keuntungan bagi WP terkait dengan kepastian hukum dan kemudahaan dalam menghitung total pajak, aparatur pajak tidak harus melakukan audit terhadap transaksi yang dilakukan oleh WP kepada perusahaan yang memiliki hubungan istimewa. Lebih lanjut mengenai kesepakatan harga transfer APA ini di atur dalam Peraturan Menteri Keuangan Republik Indonesia Nomor 22/PMK.03/2020 tentang Tata Cara Pelaksanaan Kesepakatan Harga Transfer (Advance Pricing Agreement).

Advance Pricing Agreement jika kita telaah lebih jauh merupakan bagian dari suatu jenis Perjanjian atau Kontrak, tepatnya perjanjian yang bersumber dari hukum publik. Penggolongan perjanjian yang berdasarkan sumber hukumnya digolongkan menjadi 5 (lima) jenis, yaitu ;

a. Perjanjian yang sumbernya dari hukum keluarga, seperti perjanjian kawin;

b. Perjanjian yang sumbernya dari hukum benda, seperti perjanjian jual beli;

c. Perjanjian yang menimbulkan kewajiban seperti perjanjian obligatoir;

d. Perjanjian yang sumbernya dari hukum acara, biasa disebut dengan istilah bewijsovereenkomst;

e. Perjanjian yang sumbernya dari hukum publik, biasa disebut dengan istilah publiekrechtelijke Overeenkomst.

Istilah hukum perjanjian atau kontrak sendiri merupakan terjemahan dari bahasa Inggris yaitu Contract Law, sedangkan dalam bahasa Belanda disebut dengan istilah Overeenskomstrecht. 5 Dalam Praktik, istilah Kontrak atau Perjanjian terkadang masih banyak disalah pahami oleh para pihak seolah memiliki pengertian yang berbeda. Kitab Undang - Undang Hukum Perdata (Burgerlijk Wetboek) menjelaskan Contract \& Overeenkomst memiliki arti yang sama. Hal tersebut dapat dilihat dari judul Buku III titel Kedua tentang "Perikatan - Perikatan yang Lahir dari Kontrak atau Perjanjian" yang

2 Undang - Undang Nomor 7 Tahun 1983 sebagaimana telah diubah dengan Undang - Undang Nomor 17 Tahun 2000 tentang Pajak Penghasilan.

${ }^{3}$ Penjelasan pasal 18 Ayat (3a) Undang - Undang Nomor 17 Tahun 2000 tentang Pajak Penghasilan. 59.

${ }^{4}$ Handri Raharjo, Hukum Perjanjian di Indonesia, (Yogyakarta: Pustaka Yustisia, 2009),

5 Salim H.S., Hukum Kontrak : Teori dan Teknik Penyusunan Kontrak Cet. II, (Jakarta: Sinar Grafika, 2004), 3. 


\section{ADVANCE PRICING AGREEMENT \\ DALAM PERSPEKTIF HUKUM PERJANJIAN}

diartikan dari bahasa aslinya yaitu bahasa belanda "Van verbintenissen die uit contract of overeenkomst geboren worden". ${ }^{6}$ Agus Yudha Hernoko memberikan pengertian sama antara kontrak dengan perjanjian, hal ini disebabkan fokus kajian beliau berdasarkan pada perspektif Burgerlijk Wetboek (BW), di mana tidak ada perbedaan arti antara perjanjian / persetujuan (overeenkomst) dan kontrak (contract). Selain itu, dalam praktek kedua istilah tersebut juga digunakan dalam kontrak komersil seperti: perjanjian jual beli, sewa menyewa, kontrak kerja sama. ${ }^{7}$ Dalam artikel ini penulis akan menggunakan kedua istilah diatas bersama - sama, bukan berarti penulis tidak konsisten dalam menggunakan istilah tersebut, tetapi untuk memudahkan dalam memahami setiap kalimat yang disusun.

Pasal 1313 Ayat (1) BW menyebutkan perjanjian adalah suatu perbuatan dengan mana satu orang atau lebih mengikatkan dirinya terhadap satu orang lain atau lebih. Dengan demikian peristiwa tersebut menimbulkan suatu hubungan hukum antara para pihak yang dinamakan perikatan. Menurut Subekti "Suatu perjanjian adalah suatu peristiwa dimana seseorang berjanji kepada seorang lain atau dimana dua orang itu saling berjanji untuk melaksanakan sesuatu hal". ${ }^{8}$ Dari perjanjian tersebut melahirkan suatu perikatan antara kedua orang yang membuatnya, baik itu berupa janji - janji ataupun kewajiban untuk melakukan sesuatu baik yang diucapkan maupun dituangkan dalam bentuk tulisan.

Selain melalui perjanjian, perikatan dapat pula lahir melalui Undang Undang (vide Pasal 1233 BW) atau dengan perkataan lain ada perikatan yang lahir dari perjanjian dan perikatan yang lahir dari Undang - Undang. Meskipun pada dasarnya yang paling banyak adalah perikatan yang dilahirkan dari perjanjian, dan tiap perikatan adalah untuk memberikan sesuatu, untuk berbuat sesuatu atau untuk tidak berbuat sesuatu (vide Pasal 1234 BW). Perikatan yang lahir dari perjanjian melahirkan hubungan hukum yang menempatkan hak dan kewajiban kepada para pihak yang terikat didalam perjanjian tersebut berdasarkan atas kemauan dan kehendak sendiri dari para pihak yang bersangkutan yang mengikatkan diri tersebut. Sedangkan perikatan yang lahir dari Undang - Undang disebabkan oleh adanya suatu peristiwa tertentu melahirkan hubungan hukum yang menempatkan hak dan kewajiban di antara para pihak yang terikat didalamnya, tetapi bukan berasal dari kehendak atau kemauan para pihak melainkan sudah diatur dan ditentukan oleh Undang - Undang.

Dalam ruang lingkup APA, tidak dapat dipungkiri penerimaan negara dalam sektor pajak merupakan salah satu sumber pendapatan negara yang sangat penting, namun tidak juga dapat dihindari jika pemerintah

6 Agus Yudha Hernoko, Hukum Perjanjian (Asas Proposionalitas dalam Kontrak Komersial, (Jakarta: Kencana Prenadamedia Group, 2010), 13.

7 Ibid

8 Subekti, Hukum Perikatan. Cet. XXI, (Jakarta: PT. Intermasa, 2005), 1. 


\section{ADVANCE PRICING AGREEMENT \\ DALAM PERSPEKTIF HUKUM PERJANJIAN}

memiliki keterbatasan dalam hal menangani WP nakal terutama yang berkaitan dengan transfer pricing, maka dari itu pemerintah melalui Menteri Keuangan membuat peraturan mengenai Advance Pricing Agreement, perjanjian yang dibuat oleh pemerintah dalam hal ini diwakili oleh DJP dan WP melahirkan hubungan hukum yang mengikat kedua belah pihak, secara khusus para pihak terikat akan klausula yang diperjanjikan. Selama hubungan kontraktual itu tidak menyalahi syarat - syarat sah suatu perjanjian yang sebagaimana diatur dalam Pasal 1338 Ayat (1) BW maka perjanjian tersebut sah menurut hukum. Oleh karena itu dari latarbelakang diatas, artikel ini hendak mendeskripsikan Perjanjian Advance Pricing Agreement dari sudut pandang hukum perjanjianan, menggunakan pendekatan perundang - undangan dan pendekatan konseptual yang akan dibagi menjadi beberapa sub bahasannya antara lain hubungan hukum Perjanjian Advance Pricing Agreement, Subjek Hukum dalam Perjanjian Advance Pricing Agreement, Kehendak para pihak, keseimbangan antara hak dan kewajiban, Advance Pricing Agreement sebagai perjanjian baku, dan klausula baku dalam Perjanjian Advance Pricing Agreement.

\section{Hubungan Hukum Perjanjian Advance Pricing Agreement}

Perjanjian merupakan hal yang sangat penting dalam melahirkan suatu perikatan, karena perjanjian adalah sumber dari perikatan. Dalam bukunya Yahya Harahap menjelaskan bahwa perjanjian (verbintenis) memiliki pengertian hubungan hukum antara dua orang atau lebih di bidang harta kekayaan maupun harta benda dimana pihak satu memiliki hak yang harus diterima, dan pihak lainnya memiliki kewajiban yang harus dilaksanakan. ${ }^{9}$ Selain itu perikatan menurut Subekti dapat pula dikatakan sebagai suatu hubungan hukum antara dua belah pihak dimana salah satu pihak sebagai (Kreditur) memiliki hak untuk meminta sesuatu dari pihak yang lain (Debitur) yang memiliki kewajiban untuk memehuhi permintaan tersebut. ${ }^{10}$

Di dalam perjanjian atau kontrak ada istilah lain yang dikenal yaitu persetujuan atau didalam bahasa inggris biasa disebut dengan istilah Agreement. Memiliki makna yang sama dengan perjanjian dalam Pasal 1313 BW, agreement dalam arti yang luas dapat disimpulkan sebagai persetujuan yang memiliki akibat hukum dan tidak memiliki akibat hukum. Persetujuan memiliki karakteristik perjanjian atau kontrak jika terdapat akibat hukum yang berhubungan dengan pelanggaran terhadap kontrak didalam agreement tersebut. Dalam pengertian kesepakatan para pihak yang mempunyai akibat hukum yang mengikat, maka agreement dapat dikatakan memiliki makna yang sama dengan perjanjian. Berdasarkan uraian tersebut bisa dikatakan istilah kontrak sama dengan agreement dikarenakan agreement dalam bahasa Indonesia memiliki arti perjanjian, sedangkan perjanjian

${ }^{9}$ M. Yahya Harahap, Segi-Segi Hukum Perjanjian, (Jakarta: PT. Intermasa, 1998), 1.

10 Subekti, Hukum Perikatan..., 1. 


\section{ADVANCE PRICING AGREEMENT \\ DALAM PERSPEKTIF HUKUM PERJANJIAN}

adalah persetujuan yang melahirkan perikatan, maka dari itu istilah perjanjian, kontrak, ataupun persetujuan memiliki pengertian yang sama.

Dewasa ini masih banyak masyarakat awam yang belum mengenal apa itu Advance Pricing Agreement (APA), APA atau dalam bahasa Indonesianya dikenal dengan istilah Kesepakatan Harga Transfer adalah kesepakatan bersama dalam bentuk Perjanjian Tertulis antara Direktorat Jenderal Pajak (DJP) dan Wajib Pajak (WP) atau Direktorat Jenderal Pajak dengan otoritas pajak pemerintah Mitra P3B yang melibatkan wajib pajak untuk menyepakati kriteria - kriteria dalam penentuan harga transfer dan/atau menentukan harga wajar atau laba wajar dimuka. ${ }^{11}$ Kriteria kriteria yang dimaksud terkait dengan penentuan metode transfer pricing yang digunakan serta faktor - faktor yang mempengaruhi asumsi kritikal (critical assumptions), bagi otoritas pajk dan wajib pajak, APA dapat dikatakan sebagai salah satu jalan keluar terkait pemecahan kasus transfer pricing. Hal tersebut disebabkan APA merupakan salah satu dari bentuk Advance Ruling System, yaitu sebuah sistem dalam perpajakan yang digunakan oleh WP untuk mendapatkan kepastian terhadap transaksi bisnisnya.

Sengketa diantara otoritas pajak juga menjadi salah satu point penting tujuan dilaksanakannya APA, sengketa tersebut berhubungan dengan penerapan pajak berganda (double taxation) bagi WP maupun mencegah terjadinya double non-taxation atau penghasilan tidak kena pajak di negara manapun tempat WP melaksanakan transaksi bisnisnya. APA memiliki dua model yaitu "unilateral" maupun "multilateral". APA dengan model unilateral ialah kesepakatan harga transfer antara WP dengan hanya satu otoritas pajak di satu negara saja sehubungan dengan metode transfer pricing yang akan digunakan untuk transaksi - transaksi tertentu dalam satu periode. Model pertama ini biasanya digunakan oleh WP yang hanya memiliki perusahaan di satu negara saja tanpa adanya cabang di negara lain atau biasa dikenal dengan istilah perusahaan lokal. Sementara APA dengan model multilateral ialah kesepakatan harga transfer antara WP dengan lebih dari satu otoritas pajak, APA model ini yang sekarang banyak digunakan oleh perusahaan multinasional. ${ }^{12}$

Indonesia sendiri sudah lama mengenal dan berupaya mencegah penyalahgunaan transfer pricing, usaha tersebut dimulai dengan dikeluarkannya Undang - Undang Nomor 7 Tahun 1983 tentang Pajak Penghasilan. Lebih lanjut, pada tahun 2001, Direktorat Jenderal Pajak (DJP) pernah mengeluarkan draft mengenai Pedoman Pembuatan Perjanjian Penentuan Harga Transaksi (Advance pricing Agreement) akan tetapi keinginan

11 Lihat Pasal 1Ayat (5) Peraturan Menteri Keuangan Republik Indonesia Nomor 22/PMK.07/2020 Kesepakatan Harga Transfer (Advance Pricing Agreement)

12 Awwaliatul Mukaromah, 'Apa Itu Advance Pricing Agreement?', ddtc news, 2019, https:// news.ddtc.co.id/apa-itu-advance-pricing-agreement-15179?page_y=2100.

diakses 06 Mei 2020 


\section{ADVANCE PRICING AGREEMENT \\ DALAM PERSPEKTIF HUKUM PERJANJIAN}

tersebut baru terwujud pada tahun 2010 saat Direktorat Jenderal Pajak mengeluarkan Peraturan DJP Nomor PER-69/PJ/2010 tentang Kesepakatan Harga Transfer (Advance Pricing Agreement). Dan dilanjutkan dengan Peraturan Pelaksanaannya oleh Peraturan Menteri Keuangan Nomor 7/PMK.03/2015 yang diperbaharui dengan Peraturan Menteri Keuangan Republik Indonesia Nomor 22/PMK.03/2020 tentang Tata Cara Pelaksanaan Kesepakatan Harga Transfer (Advance Pricing Agreement).

Hubungan Hukum timbul dari perikatan, sedangkan perikatan sendiri menimbulkan perjanjian yang berisi hak dan kewajiban dari para pihak yang membuatnya. Hubungan Hukum yang ada dalam pelaksanaan Perjanjian APA merupakan Hubungan Hukum antara pemerintah yang dalam hal ini diwakili oleh Direktorat Jenderal Pajak (DJP) dan WP, dan/atau Direktorat Jenderal Pajak (DJP) dengan Otoritas Pajak Negara lain yang melibatkan WP yang akan dijelaskan dibawah ini, yaitu;

1. Hubungan Hukum antara Direktorat Jenderal Pajak (DJP) dengan WP, apabila dilihat dari sudut pandang sifatnya, maka hubungan hukumnya dapat disebut dengan Perjanjian Publik. Perjanjian Publik sendiri merupakan Perjanjian atau kesepakatan dimana salah satu pihak yang membuat perjanjian adalah pemerintah yang berwenang membuat perjanjian dibidang hukum privat dan melaksanakan semua kewenangannya kecuali yang telah diatur oleh Undang - Undang. Pemerintah yang merupakan bagian dari badan hukum publik dapat melaksanakan perbuatan hukum dibidang hukum privat.13 Dalam Perjanjian APA, salah satu pihak yang membuat perjanjiannya adalah Negara, yang dalam hal ini diwakili oleh Direktorat Jenderal Pajak (DJP). Hasil kesepakatan antara DJP dengan WP tersebut dituangkan dalam bentuk Naskah APA yang ditanda tangani oleh Direktorat Jenderal Pajak dan Wajib Pajak. ${ }^{14}$

2. Hubungan Hukum antara DJP dan relasi otoritas pajak negara lain, apabila dilihat dari sudut pandang pelakunya, maka hubungan hukumnya dapat disebut sebagai Kontrak Internasional. Kontrak Internasional menurut Willis L.M. Reese adalah kontrak - kontrak yang pelakunya merupakan dua negara atau lebih. Kontrak tersebut dapat dibuat oleh negara dengan negara, negara dengan pihak swasta dari negara lain, atau antar pihak swasta di dua negara yang berbeda. ${ }^{15}$ Adapun Sudargo Gautama menegaskan bahwa Kontrak Internasional

13 Herlien Budiono, Ajaran Umum Hukum Perjanjian dan Penerapannya di Bidang Kenotariatan, (Bandung: PT. Citra Aditya Bakti, 2009), 16.

14 Lihat Pasal 15 Ayat (12) Peraturan Menteri Keuangan Nomor 22/PMK.03/2020

15 Willis L.M. Reese, "The Law Governing International Contract" dalam Hukum Kontrak (Memahami Kontrak dalam Perspektif Filsafat, Teori, Dogmatik, dan Praktik Hukum), ed. Muhammad Syaifuddin (Bandung: Mandar Maju, Bandung, 2012), 280. 


\section{ADVANCE PRICING AGREEMENT \\ DALAM PERSPEKTIF HUKUM PERJANJIAN}

adalah Kontrak Nasional yang terdapat unsur - unsur luar negeri atau "foreign element". ${ }^{16}$

\section{Subjek Hukum Dalam Perjanjian Advance Pricing Agreement}

Subjek hukum atau dalam bahasa belanda dikenal dengan istilah rechtsubject atau dalam bahasa inggris disebut law of subject pada dasarnya dapat dikatakan sebagai pendukung hak dan kewajiban yang secara kodrat sudah melekat pada seseorang sejak dia dilahirkan sampai dia mati, selain itu dimilik pula oleh badan hukum yang menurut perundang - undangan dikatakan sebagai subhek hukum. Subjek Hukum sendiri menurut Chidir ali ialah "setiap pihak yang menjadi pendukung hak dan kewajiban dalam melakukan hubungan hukum. Subjek hukum berhak atas hak hak subjektif dan pelaku dalam hukum objektif". ${ }^{17}$

Dan saat ini bisa dikatakan jika setiap manusia kodrati itu adalah pendukung hak yang timbul karena perikatan maupun Undang - Undang. Menurut Pasal 2 Ayat (1) BW, berlakunya seseorang sebagi pendukung hak (subjek hukum), dimulai pada saat dia dilahirkan dan berakhir pada saat dia meninggal dunia. Akan tetapi terdapat pengecualian, yaitu apabila anak yang ada dalam kandungan seorang wanita dianggap sebagai telah lahir, jika kepentingan hukum anak menghendakinya, antara lain yaitu; perwalian oleh ayah ataupun ibu (vide Pasal $348 \mathrm{BW}$ ), mewarisi harta peninggalan (vide Pasal 836 BW), menerima wasiat dari pewaris (vide Pasal 899 BW), menerima hibah (vide Pasal 1679 BW).

Selain manusia sebagai subjek hukum, dalam hukum terdapat pula badan-badan atau perkumpulan-perkumpulan yang juga dapat mempunyai hak dan melakukan perbuatan hukum seperti layaknya seorang manusia, mempunyai harta sendiri yang berbeda dengan harta pribadi, ikut serta dalam melakukan perbuatan hukum dengan perantara pengurusnya, dan dapat menjadi penggugat atau tergugat dihadapan hakim. ${ }^{18} \mathrm{R}$. Rochmat Soemitro berpendapat, badan hukum (rechtpersoon) adalah badan hukum yang dapat mempunyai harta, hak dan kewajiban seperti orang pribadi. ${ }^{19}$ dari pendapat beberapa ahli diatas, dapat disimpulkan bahwa badan hukum adalah suatu perkumpulan orang atau organisasi yang mempunyai hak dan kewajiban serta harta kekayaan sendiri yang terpisah dari harta kekayaan para pengurus, yang mampu melakukan perbuatan hukum, dan dapat menjadi penggugat atau tergugat dihadapan hakim yang diwakili oleh para pegurusnya. Perjanjian Advance Pricing Agreement dalam suatu hubungan hukum yang terjadi antara DJP dan WP selaku subjek hukummerupakan

16 Ibid.,

17 Chidir Ali, Badan Hukum, (Bandung: PT.Alumni, 2005), 6.

18 Subekti, Hukum Perikatan..., 21.

19 R. Rochmat Soemitro, "Perseroan Terbatas - Aspek Hukum", dalam Hukum Perusahaan Step by Step Prosedur Pendirian Perusahaan, ed. Handiri Raharjo, (Jakarta: Pustaka Yustisia, 2013), 18. 


\section{ADVANCE PRICING AGREEMENT \\ DALAM PERSPEKTIF HUKUM PERJANJIAN}

Perbuatan Hukum bersegi dua atau yang biasa kita kenal dengan Perjanjian atau Kontrak Timbal Balik. Kontrak timbal balik adalah kontrak yang meletakkan hak dan kewajiban kepada kedua pihak yang membuat kontrak. ${ }^{20}$

\section{Kehendak Para Pihak Dalam Perjanjian Advance Pricing Agreement}

Kehendak para pihak yang akan mengadakan suatu perjanjian baik aspek formil dan materiil mendapat perhatian khusus sebelum disahkannya dalam suatu bentuk kontrak dan para pihak telah yakin bahwa isi kontrak telah mewakili kehendak masing - masing pihak, hal ini disebabkan untuk menghindari kemungkinan timbulnya istilah That's not what I want. Kata sepakat timbul apabila para pihak telah mengetahui hak dan kewajibannya masing - masing dalam suatu kontrak yang telah disepakati. Kehendak para pihak merupakan wujud nyata dari adanya asas konsensualisme yang menurut Agus Yudha Hernoko, asas konsensualisme mempunyai hubungan yang erat dengan asas kebebasan berkontrak yang terdapat dalam Pasal 1338 (1) BW. Dalam Pasal tersebut dikatakan bahwa "semua perjanjian yang dibuat secara sah berlaku sebagai Undang - Undang bagi mereka yang membuatnya". Maksud dari asas ini adalah kehendak para pihak untuk sepakat dan mengikatkan diri dan melahirkan kepercayaan diantara para pihak yang terlibat dalam perjanjian tersebut. Pasal 1320 KUHPerdata mengandung asas yang paling mendasar dari hukum perjanjian, yaitu "Asas Konsensualisme" yang menentukan adanya perjanjian (raison d'etre, het bestaamwaarde). ${ }^{21}$

Dalam hukum perjanjian, asas konsesualisme tidak mungkin terlepas dari asas kebebasan berkontrak. Suatu perjanjian dapat dibatalkan apabila salah satu dari pihak yang membuatnya tidak ada kata sepakat. Kata sepakat dari para pihak tidak dapat dipaksa untuk memberikan kata sepakat. Dalam hukum perjanjian subjek hukum bebas untuk melakukan perjanjian dengan siapapun yang dia hendaki, yang diatur dalam BW hanyalah terkait pihak pihak yang dianggap tidak cakap melakukan perbuatn hukum, hal itu bisa dilihat dari Pasal 1330 BW. Dari ketentuan Pasal tersebut dapat disimpulkan bahwa semua orang bebas untuk menentukan pihak mana yang ingin diajak untuk membuat kontrak/perjanjian, selama pihak tersebut cakap untuk melakukan perbuatan hukum. Akan tetapi terdapat pengecualian dalam Pasal 1331 BW, dikatakan meskipun salah satu dari pihak tersebut tidak cakap melakukan perbuatan hukum, selama pihak lain didalam perjanjian/kontrak tersebut tidak mempermasalahkannya, maka perjanjian/kontrak tersebut tetap sah mengikat para pihak yang membuatnya (vide Pasal 1330 BW).

${ }^{20}$ Muhammad Syaifuddin, Hukum Kontrak..., 149.

21 Agus Yudha Hernoko, "Reinterpretasi dan Reorientasi Pemahaman Prinsip Prinsip Hukum Perjanjian", Yuridika, Vol. 17, No.6 (Surabaya 2002), 547-549. 


\section{ADVANCE PRICING AGREEMENT \\ DALAM PERSPEKTIF HUKUM PERJANJIAN}

Apabila kita mempelajari BW, ternyata asas kebebasan berkontrak itu bukannya bebas mutlak. Terdapat batasan - batasan yang ditentukan oleh BW terhadap asas kebebasan berkontrak yang membuat asas tersebut menjadi asas yang tidak tak terbatas. Pasal 1320 Ayat (1) BW menjelaskan bhwa perjanjian/kontrak dikatakan tidak sah apabila dalam pembuatannya tidak ada kata sepakat baik oleh salah satu pihak ataupun kedua belah pihak Pasal tersebut mengandung arti bahwa kebebasan para pihak untuk membuat perjanjian dibatasi oleh kata sepakat dari pihak lainnya. Dengan demikian Asas Kebebasan Berkontrak kebebasannya terbatas oleh kesepakatan para pihak. Lebih lanjut Pasal 1320 Ayat (2) BW dapat pula diartikan bahwa kebebasan para pihak untuk membuat perjanjian dibatasi oleh cakapnya para pihak yang membuat perjanjian, seseorang yang belum dewasa atau dibawah pengampuan tidak mempunyai kecakapan untuk membuat perjanjian/kontrak (vide Pasal 1330 BW). Syarat selanjutnya dalam Pasal 1320 Ayat (3) BW menentukan tentang objek perjanjian haruslah dapat ditentukan. objek tersebut harus ada atau sekurang - kurangnya bisa ditentukan, yang diperjanjikan harus jelas bentuknya, tidak wajib untuk menyebutkan berapa jumlahnya, selama dapat ditentukan bentuknya objek perjanjian tersebut. Syarat bahwa objek perjanjian harus tertentu atau dapat ditentukan, hal tersebut berguna sebagai penentu hak dan kewajiban para pihak yang membuatnya untuk mencegah terjadinya sengketa dikemudian hari dalam pelaksanaan perjanjian tersebut. Apabila Objek perjanjian tersebut tidak jelas, yang mengakibatkan perjanjian tesebut tidak mampu dilaksanakan, maka dianggap tidak ada objek perjanjian dan akibat hukumnya perjanjian tersebut batal demi hukum. Pasal 1320 Ayat (4) BW jo. Pasal 1337 BW menyebutkan para pihak tidak dapat membuat perjanjian apabila didalam perjanjian tersebut terdapat objek atau klausula-klausula yang dilarang oleh Undang - Undang. Sehubungan dengan hal tersebut, dalam Perjanjian Advance Pricing Agreement, kehendak para pihak dapat dilihat dari awal ketika WP membuat permohonan tertulis kepada DJP sehubungan dengan keinginan untuk diadakannya Perjanjian Advance Pricing Agreement sampai dengan berakhirnya masa perjanjian. Pada Prinsipnya, para pihak dalam APA bebas untuk menentukan nilai dari harga wajar ataupun laba wajar, penentuan harga wajar atau laba wajar tersebut dilakukan dengan sistem negosisasi baik dari segi teknis maupun harga sehingga diperoleh harga yang wajar ataupun laba yang wajar.

\section{Keseimbangan Hak \& Kewajiban Perjanjian Advance Pricing Agreement}

Dalam menjalin suatu kontrak, para pihak senantiasa menghendaki agar apa yang disepakati bersama dapat terpenuhi sebagaimana mestinya pemenuhan hak dan kewajiban. Sehubungan dengan hal tersebut masalah itikad baik dan etika bisnis yang berlandaskan pada prinsip kejujuran, kepercayaan, transparansi, kepatutan, keadilan dan saling menguntungkan 


\section{ADVANCE PRICING AGREEMENT \\ DALAM PERSPEKTIF HUKUM PERJANJIAN}

mampu mendorong terciptanya praktek perdagangan yang sehat. ${ }^{22}$ Hak dan kewajiban bersifat timbal balik dalam suatu transaksi dimana perangkat hak dan kewajiban salah satu pihak adalah berbanding terbalik dengan perangkat hak dan kewajiban pihak lainnya, namun dalam APA terdapat kecenderungan DJP mendominasi haknya sebagai kewajiban yang banyak diimplikasikan sebagai kompensasi dari kewajiban WP (tidak seimbang). DJP memiliki wewenang untuk menentukan perlu atau tidaknya diadakan Perjanjian APA terhadap WP yang mengajukannya, selain itu DJP juga berwenang untuk mendapatkan informasi sebanyak - banyaknya dari WP berkaitan dengan Objek Pajak yang akan dinegosiasikan dengan WP. Sementara itu, WP adalah pihak yang mendominasi banyak kewajiban dengan sedikit hak untuk membuat perjanjian.

Berdasarkan hal tersebut, asas konsensualisme mempunyai hubungan erat dengan asas kebebasan berkontrak sehingga salah satu cara yang bisa ditempuh untuk mencegah terjadinya ketidaksimbangan antara hak dan kewajiban adalah dalam penyusunan kontrak sebaiknya sesuai dengan sikap yang dikenal dengan istilah win - win attitude yang dilandasi itikad baik. Dengan melihat pada hakikat asas kebebasan berkontrak yang sebenarnya, kedudukan para pihak didalam perjanjian akan menjadi imbang karena asas ini tidak menempatkan para pihak untuk saling berhadapan, menjatuhkan dan mematikan sebagai lawan kontrak, tetapi sebaliknya asa ini menempatkan para pihak sebgai partner - mitra kontrak. Dengan pemahaman ini dapat menciptakan kondisi yang menguntungkan bagi para pihak yang membuat perjanjian tersebut, suatu kondisi yang dilandasi sikap win - win attitude yang akhirnya melahirkan win - win solution. ${ }^{23}$

\section{Perjanjian Advance Pricing Agreement Sebagai Perjanjian Baku}

Secara prinsip, klausula - klausula didalam perjanjian, dibuat oleh para pihak yang terikat didalam perjanjian tersebut, tujuannya agar klasula tersebut dapat dilaksanakan sebaik mungkin dan tidak bertentangan dengan Undang - Undang. Ada kalanya posisi para pihak didalam perjanjian sering kali tidak seimbang, yang dapat menyebabkan lahirnya perjanjian yang hanya menguntungkan salah satu pihak saja. Posisi salah satu pihak yang lebih tinggi biasanya memperoleh keuntungan yang lebih banyak dari pihak lainnya didalam perjanjian disebut dengan perjanjian baku. Di Indonesia perjanjian baku juga dikenal dengan istilah "perjanjian standar". Dalam Kamus Besar Bahasa Indonesia, kata standar memiliki makna ukuran tertentu yang digunakan sebagai dasar, sedangkan kata baku memiliki makna tolak ukur yang berlaku untuk kuantitas atau kualitas yang diterapkan, perjanjian

22 Basuki Rekso Wibowo,"Prinsip - Prinsip dasar Arbitrase sebagai Alternatif Penyelesaian Sengketa Dagang di Indonesia", Yuridika, Vol.16, No.6 (Surabaya 2001), 551.

23 Agus Yudha Hernoko,"Pengembangan Kontrak "Win - Win" Didunia Bisnis", Amrta Vol.1 No.1 (Surabaya 2000) 40 - 41. 


\section{ADVANCE PRICING AGREEMENT \\ DALAM PERSPEKTIF HUKUM PERJANJIAN}

baku juga dikenal dengan istilah take it or leave it. ${ }^{24}$ Artinya salah satu pihak memiliki hak untuk memilih menyetujui perjanjian atau menolak perjanjian. Baik didalam BW maupun peraturan perundang - undangan lainnya tidak memuat mengharuskan atau melarang seseorang untuk terikat dalam suatu perjanjian, dan dengan diterapkannya asas konsensualisme menurut hukum perjanjian Indonesia menegaskan adanya kebebasan ini.

Berkembangnya perjanjian baku selamanya tidak selalu berkonotasi negatif, karena tujuannya adalah memberikan kemudahan (kepraktisan) bagi para pihak yang membuat kontrak. Oleh karena itu, menurut Mariam Darus Badrulzaman mendefinisikan kontrak baku atau perjanjian standar sebagai kontrak atau perjanjian yang isinya dibakukan dan dituangkan dalam bentuk formulir. ${ }^{25}$ Disatu pihak, kontrak baku sangatlah menguntungkan, jika melihat waktu, tenaga dan biaya yang dapat diminimalisir. Akan tetapi, di pihak lainnya, perjanjian baku melibatkan pihak yang tidak terlibat dalam pebuatan klausula - klausula dalam perjanjian menjadi pihak yang langsung atau tidak langsung dirugikan, karena dalam perjanjian tersebut di sisi dia sebagai pemegang hak dari perjanjian yang dibuat, di sisi lain dia memiliki kewajiban untuk menerima seluruh isi klausula perjanjian tersebut. ${ }^{26}$ dalam perjanjian baku hampir secara keseluruhan klausulanya sudah dibakukan oleh penggunanya dan pihak lain pada hakekatnya tidak memiliki kesempatan sama sekali untuk mengubah isi dari klausula baku tersebut. Adapun yang belum dibakukan dalam perjanjian baku antara lain terkait masalah harga, jumlah, waktu dan hal lain yang secara spesifik dari objek yang diperjanjikan. Dapat disimpulkan perjanjian baku yang dibakukan bukanlah formulir perjanjian baku, akan tetapi klasula baku.27

Mariam Darus Badrulzaman menggolongkan jenis kontrak baku menjadi 3 (tiga) jenis, yaitu²8;

a. Kontrak baku sepihak, yaitu kontrak yang isinya ditentukan oleh pihak yang kuat kedudukannya;

b. Kontrak baku yang ditetapkan oleh negara;

c. Kontrak baku yang dibuat oleh Notaris atau Advokat, yang disediakan untuk memenuhi permintaan dari masyarakat atau biasa dikenal sebagai "contract model".

Karakteristik perjanjian baku berbeda dan tidak dimiliki oleh perjanjian lainnya yaitu; dibuat oleh salah satu pihak saja dan tidak melalui suatu bentuk perundingan, isi perjanjian yang telah distandarisasi, klausul yang ada didalamnya biasanya merupakan klausul yang telah menjadi

\footnotetext{
24 Muhammad Syaifuddin, Hukum Kontrak..., 216

25 Ibid., 217.

26 Ibid., 218.

27 Ibid.,

28 Ibid., 219.
} 


\section{ADVANCE PRICING AGREEMENT \\ DALAM PERSPEKTIF HUKUM PERJANJIAN}

kebiasaan secara luas dan berlaku secara terus menerus dalam waktu yang lama. ${ }^{29}$ Keabsahan kontrak baku menurut Sutan Remy Sjahdeini bahwa didalam dunia bisnis, eksistensi perjanjian baku bukan lagi merupakan masalah yang harus diributkan, karena tanpa adanya perjanjian baku kegiatan transaksi bisnis tidak akan berlangsung lama, perjanjian baku dibutuhkan dan oleh karena itu perjanjian baku dapat diterima oleh masyarakat luas. ${ }^{30}$ Selain itu meskipun keabsahan berlakunya memang tidak perlu diributkan, akan tetapi masih perlu dipermasalahkan terkait perjanjian baku yang sangat "berat sebelah" dan mengandung "klausul yang secara tidak wajar sangat memberatkan bagi pihak lainnya", sehingga perjanjian tersebut yang menindas dan tidak adil. Arti "berat sebelah" adalah perjanjian tersebut biasanya hanya mencantumkan hak untuk salah satu pihak saja "pihak pembuat perjanjian baku tersebut" tanpa menjabarkan apa yang menjadi kewajban pihaknya dan sebaliknya menyebutkan kewajiban pihak lain, tanpa menyebutkan hak yang diperolehnya. Dari uraian diatas dapat disimpulkan sebenarnya perjanjian baku tidak perlu dipermasalahkan lagi keabsahannya, yang menjadi masalah perlu dibuat aturan main agar klausula - klausula dalam perjanjian baku itu dapat diterima oleh seluruh pihak yang membuatnya. ${ }^{31}$

Perjanjian Advance Pricing Agreement yang dibuat oleh para pihak, yaitu DJP dan WP atau Otoritas Pajak Negara Mitra atau Yuridiksi Mitra lazimnya dibuat dalam bentuk kontrak baku menyangkut penentuan harga wajar atau laba wajar dan persyaratan administrasinya yaitu ketentuan yuridisnya. Dasar Hukum Peraturan Standar tentang Perjanjian Advance Pricing Agreement adalah Pasal 23A Undang - Undang Dasar Negara Republik Indonesia Tahun 1945 yaitu "pajak dan pungutan lain yang bersifat memaksa untuk keperluan negara diatur dengan Undang - Undang. Undang - undang yang dimaksud adalah Undang - Undang Republik Indonesia Nomor 6 Tahun 1983 tentang Ketentuan Umum dan Tata Cara Perpajakan sebagaimana telah beberapa kali dirubah terakhir dengan Undang - Undang Republik Indonesia Nomor 16 Tahun 2009. Sedangkan dasar hukum Perjanjian Advance Pricing Agreement diatur dalam Peraturan Direktorat Jenderal Pajak Nomor PER-69/PJ/2010 tentang Kesepakatan Harga Transfer (Advance Pricing Agreement) yang dipertegas dengan Peraturan Menteri Keuangan Republik Indonesia Nomor 22/PMK.03/2020 tentang Tata Cara Pelaksanaan Kesepakatan Harga Transfer (Advance Pricing Agreement).

${ }^{29}$ Sriwati,"Perlindungan Hukum bagi Para Pihak dalam Perjanjian Baku". Jurnal Yustika, Media Hukum EKeadilan, Vol.3 No. 2 (Surabaya 2000), 175.

${ }^{30}$ Muhammad Syaifuddin Hukum Kontrak..., 221.

${ }^{31}$ Ibid., 


\section{ADVANCE PRICING AGREEMENT \\ DALAM PERSPEKTIF HUKUM PERJANJIAN}

\section{Klausula Baku Sebagai Upaya Perlindungan Kepentingan}

Klausula baku merupakan klausula yang didalam suatu perjanjian atau kontrak sudah dibuat baku sebagai kontrak bakunya untuk tujuan perjanjian atau kontrak tersebut. Pihak yang lebih tinggi kedudukannya menekankan maksud dan tuntutan tanggung jawab kepada pihak yang lebih rendah kedudukannya karena tidak menghendaki adanya kegagalan dalam perjanjian tersebut. Asas kebebasan berkontrak yang bertanggung jawab mampu memelihara keseimbangan sebagai modal "pengembangan kepribadian, terbatas oleh tanggung jawab para pihak, yang mendukung kedudukan seimbang diantar para pihak sehingga sebuah kontrak akan bersifat stabil dan memberikan keuntungan bagi kedua pihak. ${ }^{32}$

Mengingat klausula baku dalam Perjanjian APA adalah untuk kepentingan negara dan kepastian wajib pajak terhadap kegiatan usahanya serta mencegah terjadinya praktek transfer pricing dengan ketentuan peraturan standar dalam perjanjian yang ditandatangi sehingga para pihak terikat pada peraturan standar didalmnya maka klausula baku tersebut berfungsi sebagai perlindungan bagi para pihak. Pada umumnya, dalam Perjanjian APA klausula baku dibuat karena yang diperjanjikan disini berkaitan dengan penerimaan negara di bidang perpajakan dan pihak DJP menginginkan hasil yang terbaik dari perjanjian yang disepakati. Bentuk baku dari Perjanjian APA yang diatur dalam Peraturan Direktorat Jenderal Pajak Nomor PER-69/ PJ/2010 dan Peraturan Menteri Keuangan Nomor 22/PMK.03/2020 sebagai peraturan pelaksananya. Berdasarkan hal tersebut, klausula yang dibakukan adalah : Identitas Para Pihak (DJP sebagai Pihak Pertama dan Wajib Pajak/Otoritas Pajak Negara Mitra atau Yuridiksi Mitra sebagai pihak Kedua). Jangka waktu Perjanjian, Prosedur dan tata cara pengajuan, Pembahasan, Naskah APA, Pelaksanaan, Evaluasi dan Pembaharuan APA.

\section{KESIMPULAN}

Advance Pricing Agreement merupakan perjanjian tertulis yang dibuat oleh DJP dan WP untuk menyepakati kriteria - kriteria dalam penentuan harga transfer dan/atau harga wajar laba wajar dimuka. APA jika ditinjau dari perspektif hukum perjanjian dapat dikatakan merupakan hubungan hukum dibidang keperdataan antara DJP dan WP atau antara DJP dan otoritas pajak negara mitra yang sama - sama memiliki kehendak. Dari sudut pandang hukum perjanjian, APA termasuk dalam kategori perjanjian baku, mengapa dikatakan sebagai perjanjian baku? Karena klausula - klausula didalam perjanjian APA hampir secara keseluruhan telah di atur oleh Undang - Undang. WP selaku pihak yang terlibat dapat dipastikan tidak memiliki kesempatan untuk mengubah atau merundingkan klausula klausula dalam perjanjian APA, yang dapat dirundingkan hanyalah 


\section{ADVANCE PRICING AGREEMENT \\ DALAM PERSPEKTIF HUKUM PERJANJIAN}

berkaitan dengan harga, jumlah, waktu atau hal lain yang secara spesifik terkait dengan objek perjanjian. Tidak adanya keseimbangan hak dan kewajiban antara DJP dan WP menjadi masalah yang perlu dikaji lebih lanjut. Dapat dikatakan dengan adanya klausula baku dalam perjanjian APA sebenarnya termasuk perjanjian yang tidak terlalu menguntungkan bagi WP, karena WP memiliki banyak kewajiban dengan sedikit hak, sebaliknya DJP selaku pembuat APA memiliki banyak Hak dengan sedikit kewajiban. Akan tetapi jika perjanjian APA dapat diterapkan dengan berpegang teguh pada asas konsensual, asas kebebasan berkontrak dan asas itikad baik serta dalam penerapannya menerapkan win-win solution sebagai tujuan akhir dari perjanjian, maka APA dapat menjadi solusi yang tepat bagi pemerintah dan WP dalam mengakomodir kebutuhan para pencari keadilan dibidang perpajakan. Dengan demikian dapat mengakomodir kebutuhan para pihak yang terikat di dalam perjanjian tersebut, baik itu mencegah terjadinya praktek transfer pricing, dapat menjamin penerimaan negara dari sektor pajak maupun melindungi wajib pajak dari terjadinya pajak berganda. 


\section{DAFTAR PUSTAKA}

\section{Buku}

Agus Yudha Hernoko, Hukum Perjanjian (Asas Proposionalitas dalam Kontrak Komersial. Jakarta: Kencana Prenadamedia Group, 2010

Chidir Ali, Badan Hukum. Bandung: PT.Alumni, 2005

Handri Raharjo, Hukum Perjanjian di Indonesia. Yogyakarta: Pustaka Yustisia, 2009

Herlien Budiono, Ajaran Umum Hukum Perjanjian dan Penerapannya di Bidang Kenotariatan. Bandung: PT. Citra Aditya Bakti, 2009

M. Yahya Harahap, Segi-Segi Hukum Perjanjian. Jakarta: PT. Intermasa, 1998

Muhammad Syaifuddin, Hukum Kontrak (Memahami Kontrak Dalam Perspektif Filsafat, Teori, Dogmatik dan Praktik Hukum. Bandung: Mandar Maju, 2012.

Salim H.S., Hukum Kontrak : Teori dan Teknik Penyusunan Kontrak Cet. II. Jakarta: Sinar Grafika, 2004

Subekti, Hukum Perikatan. Cet. XXI. Jakarta: PT. Intermasa, 2005

Jurnal

Agus Yudha Hernoko,"Pengembangan Kontrak "Win - Win" Didunia Bisnis", Amrta Vol.1 No.1 (Surabaya 2000)

Agus Yudha Hernoko, "Reinterpretasi dan Reorientasi Pemahaman Prinsip Prinsip Hukum Perjanjian", Yuridika, Vol. 17, No.6 (Surabaya 2002)

Basuki Rekso Wibowo,"Prinsip - Prinsip dasar Arbitrase sebagai Alternatif Penyelesaian Sengketa Dagang di Indonesia", Yuridika, Vol.16, No.6 (Surabaya 2001)

Sriwati,"Perlindungan Hukum bagi Para Pihak dalam Perjanjian Baku”. Jurnal Yustika, Media Hukum EKeadilan, Vol.3 No. 2 (Surabaya 2000)

Website

Awwaliatul Mukaromah, 'Apa Itu Advance Pricing Agreement?', https://news.ddtc.co.id/apa-itu-advance-pricing-agreement15179?page_y=2100.

Hadi Setiawan,"Kajian Transfer Pricing Dan Risikonya Terhadap Penerimaan Negara.pdf, http://www.kemenkeu.go.id/sites/default/files/2014,

\section{Undang - Undang}

Kitab Undang - Undang Hukum Perdata (BW)

Peraturan Menteri Keuangan Nomor 22/PMK.03/2020 Tentang Tata Cara Pelaksanaan Kesepakatan Harga Transfer (Advance Pricing Agreement)

Undang - Undang Dasar Negara Republik Indonesia Tahun 1945

Undang - Undang Nomor 17 Tahun 2000 tentang Pajak Penghasilan. 